\title{
INOVASI TEKNIK PENGOLAHAN LIMBAH BUAH DAN SAYUR RUMAH TANGGA
}

\author{
Jati Widyo Leksono ${ }^{1}$, Nailul Izzati ${ }^{2}$, Nanndo Yannuansa ${ }^{3}$, \\ Elly Indahwati ${ }^{4}$, Agung Samudra ${ }^{5}$ \\ ${ }^{1,2,3,4}$ Program Studi Teknik Elektro, Universitas Hasyim Asy'ari Jombang \\ ${ }^{5}$ Program Studi Teknik Mesin, Universitas Hasyim Asy’ari Jombang \\ Jatiwidyoleksono@gmail.com
}

\begin{abstract}
The Consumption of fruit and vegetables by the community is inseparable from the waste generated. Conventionally, fruit and vegetable waste is thrown away, or for people who have livestock or livestock, the waste is used for feed. This is of course very unfortunate, given the fact that optimal fruits and vegetables can be utilized. Utilization of organic waste as animal feed ingredients as conventional compost material. If organic waste is made into compost, the benefits are only given to plants. It is different if organic waste is made into animal feed, which is beneficial for livestock, and from livestock obtained from livestock manure which can be made compost. However, organic waste used for animal feed, easy to rot and voluminous (large) processing techniques are needed to improve the future of storage, facilitate storage, and to enhance the antinutritional effects that usually contain alkaloids.
\end{abstract}

Keywords: Waste, Fruit vegetable, Processing technique

Abstrak:Konsumsi buah dan sayur oleh masyarakat tidak lepas dari adaya limbah yang dihasilkan. Secara konvensional, limbah buah dan sayur dibuang begitu saja, atau bagi masyarakat yang memiliki hewan ternak atau peliharaan, limbah tersebut dijadikan pakan. Hal ini tentu saja sangat disayangkan, mengingat sebenarnya limbah buah dan sayur tersebut masih dapat dimanfaatkan secara optimal. Pemanfaatan limbah organik sebagai bahan pakan ternak ataupun sebagai kompos secara konvensional dinilai memiliki kelemahan. Jika limbah organik dijadikan kompos, manfaatnya hanya diberikan kepada tanaman. Berbeda jika limbah organik dijadikan pakan ternak, yang bermanfaat bagi ternak, dan dari ternak diperoleh kotoran ternak yang dapat dijadikan kompos. Namun, limbah organik yang dijadikan pakan ternak secara langsung, bersifat mudah membusuk dan voluminus (bulky) sehingga diperlukan inovasi teknik pengolahan limbah untuk memperpanjang masa simpannya, mempermudah penyimpanan, dan mengurangi efek anti nutrisi yang biasanya berupa suatu alkaloid.

Kata Kunci : Limbah, Buah sayur, Teknik pengolahan

\section{Pendahuluan}

\section{Konsumsi Buah dan Sayur Masyarakat Indonesia}

Buah dan sayur merupakan salah satu sumber makanan sehat. Berbagai macam vitamin, mineral, dan serat terkandung di dalamnya. Indonesia merupakan salah satu negara penghasil buah dan sayur tertinggi di dunia. Menurut data FAOSTAT (Food and Agriculture Organization of the United Nations), sejak tahun 19612017, komoditas alpukat, singkong, cabai dan lada (hijau), biji cokelat, kopi (hijau), buah tropis, jahe, kelapa sawit, beras, serta karet, menduduki peringkat 10 besar dunia, sedangkan kelapa dari Indonesia menduduki peringkat pertama dunia. Pada 2018, ekspor sayur Indonesia mengalami kenaikan. Total produksi pada periode Januari-Oktober 2018 mencapai angka 1,6 juta ton. Naik lebih dari $14 \%$ dibanding periode yang sama pada tahun sebelumnya, yang mencapai 1,4 juta ton. Nilai ekspornya meningkat lebih dari $12 \%$ dari US $\$ 116$ juta menjadi US\$130 juta. Jenis sayur andalan ekspor Indonesia antara lain 
kubis, sawi, dan kembang kol (Loedji, 2019).

Sebagai negara tropis, Indonesia memiliki aneka ragam buah dan sayur lokal. Selain menggunakan buah dan sayur lokal sebagai sumber makanan, Indonesia juga melakukan impor buah dan sayur untuk memenuhi kebutuhan konsumsinya. Dikutip dari Buletin Pemantauan Ketahanan Pangan Indonesia, pada tahun 2017, tingkat produksi buah dan sayur yang cukup tinggi di Indonesia belum diiringi dengan tingkat konsumsi yang tinggi pula. Menurut buletin tersebut, tingkat konsumsi buah dan sayur masyarakat Indonesia masih di bawah jumlah konsumsi yang disarankan oleh WHO/FAO dan Kementerian Kesehatan.

Menurut BPS dalam Statistik Indonesia 2017, kelompok buah yang paling banyak dikonsumsi masyarakat Indonesia pada tahun 2016 adalah pisang (7.007.125 ton), jeruk (2.138.474 ton), mangga (1.814.550 ton) dan rambutan (572.193 ton). Sedangkan untuk kelompok sayur, yang paling banyak dikonsumsi adalah cabe (1.961.598 ton), kubis (1.513.326 ton), bawang merah (1.446.869 ton), kangkung (297.130 ton), bayam (160.267 ton), dan kacang panjang (388.071 ton). Jumlah ini mungkin terasa banyak, namun ternyata hanya mencapai $43 \%$ dari jumlah konsumsi yang disarankan oleh badan kesehatan.

\section{Manfaat Buah dan Sayur bagi Kesehatan Tubuh}

Konsumsi buah dan sayur secara teratur dapat menjaga kesehatan fisik dan mental, di antaranya melancarkan sistem pencernaan, mencegah obesitas, mengurangi resiko terkena penyakit jantung koroner, tekanan darah tinggi/hipertensi , diabetes, kanker, meningkatkan sistem kekebalan tubuh, meningkatkan fungsi penglihatan dan memori, menguatkan tulang dan gigi, dan masih banyak lagi. Namun, penggunaan bahan kimia dalam proses budidaya buah dan sayur, menyebabkan adanya kemungkinan kandungan zat-zat yang bisa jadi mengancam kesehatan konsumennya, dan dampak negatif lainnya.

Kesadaran masyarakat tentang pentingnya menjaga kesehatan tubuh dan lingkungan, membuat sebagian orang mulai beralih ke gaya hidup sehat, back to nature, dan lebih selektif terhadap makanan yang dikonsumsinya, salah satunya dengan cara memilih bahan pangan organik sebagai sumber makanannya. Menurut Standar Nasional Indonesia (SNI) terkait tentang sistem pangan organik tahun 2002, organik merupakan istilah label yang menyatakan suatu produk telah diproduksi sesuai dengan standar sistem pangan organik serta dilakukan sertifikasi oleh Lembaga Sertifikasi Organik (LSO) yang telah diakreditasi oleh Komite Akreditasi Nasional (KAN). Sedangkan menurut Yayasan Lindungan Konsumen Indonesia (YLKI), suatu makanan organik yang diproduksi dengan sedikit / sama sekali tidak mengandung beberapa unsur kimia seperti pupuk, pestisida, hormon dan obat-obatan lainnya. Semua proses produksi pangan organic tersebut dilakukan secara alami dan alangkah baiknya memenuhi pedoman persyaratan internasional seperti tidak menggunakan suatu bibit GMO (Genetic Modified Organism atau produk rekayasa genetik) di dalam proses produksi dan tidak menggunakan suatu teknologi nirradiasi dalam mengawetkan produk (Khorniawati, 2014). 
32 | Jati widyo Leksono, dkk : Inovasi teknik pengolahan ...

\section{Metode}

Dalam penerapan inovasi teknik pengolahan limbah rumah tangga tersebut dilaksanakan dengan menggunakan beberapa metode seperti ceramah, diskusi, serta demonstrasi kepada masyarakat sekitar.

Di dalam demontrasi alat ini akan dijelaskan mengenai berbagai sisa sayur tersebut dipotong-potong, kemudian dimasukkan ke dalam suatu kotak. Kotak tersebut berisi berbagai macam saringan / filter yang tertata sedemikian rupa. Setelah limbah sayur dimasukkan, kotak besar itu diisi air dan cairan zat pelarut. Dua puluh menit kemudian, baru kita buka kran bawah kotak tersebut sehingga air hasil rendaman sayur tadi keluar.

\section{Hasil dan Pembahasan}

\section{Kandungan Limbah Sayur}

Limbah sayuran hasil dapur rumah tangga memiliki kelemahan sebagai pakan, seperti mempunyai kadar air tinggi $(91,56 \%)$ dapat menyebabkan cepat busuk sehingga kualitasnya sebagai pakan cepat menurun. Dengan demikian itu,limbah sayur yang tidak dapat diberikan langsung kepada hewan ternak perlu diolah dulu untuk mempertahankan kualitasnya. Pengolahan dengan fermentasi mampu mengawetkan kualitas sampah organik tersebut sebagai bahan pakan. Fermentasi tersebut menggunakan starter Lactobacillus bulgaricus dengan aditif dedak. Waktu yang dibutuhkan dari fermentasi adalah selama satu minggu. Setelah itu baru dapat menghasilkan beberapa produk sampah organik fermentasi dengan kecernaan bahan kering, kecernaan bahan organik, serta produksi VFA yang sama persis dengan rumput dan produksi NH3 yang lebih tinggi daripada rumput.

\section{Pemanfaatan Limbah dan Sayur untuk ditanam kembali}

Pemanfaatan limbah buah dan sayur dengan menyisakan bagian dari buah dan sayur yang dapat ditanam kembali. Tren konsumsi dari buah dan sayur menunjukkan hubungan antara tingkat penghasilan dengan pola konsumsi buah dan sayur masyarakat. Penduduk yang berpenghasilan rendah cenderung mengkonsumsi buah dan sayur dalam jumlah yang sedikit dan konsumsinya akan meningkat seiring dengan bertambahnya penghasilan mereka. Pemanfaatan limbah buah dan sayur untuk ditanam kembali dapat menjadi jalan alternatif untuk mendapatkan buah dan sayur tanpa harus membelinya setiap hari, dan mendukung gerakan zero waste.

Seperti yang disebutkan sebelumnya, bahwa faktor ekonomi bukan merupakan satu-satunya faktor penghalang bagi masyarakat Indonesia dalam mengkonsumsi buah dan sayur. Sehingga cara pemanfaatan limbah buah dan sayur ini, tidak hanya berguna bagi masyarakat menengah ke bawah dari segi ekonomi, namun juga dapat berguna bagi masyarakat menengah ke atas yang peduli dengan lingkungan. Pembahasan dalam hal ini difokuskan pada skala rumah tangga, yang umumnya mempunyai lahan ataupun ruang kosong di depan atau belakang rumah.

\section{Inovasi Teknologi Teknik Pengolahan}

Teknologi pertanian yang diperkenalkan dalam hal ini adalah FELITA dan Manutta. FELITA (Fermentasi Limbah Rumah Tangga) adalah alat yang dirancang untuk mengolah limbah makanan menjadi pupuk cair dan pupuk kompos organik. 
Sedangkan Manutta Gold B (Pengurai serta Penyubur Tanah) merupakan suatu pupuk organik nutrisi tanaman yang mengandung berbagai unsur hara makro maupun mikro yang lengkap dan bermanfaat bagi tanaman. Selain itu, terdapat mikroorganisme yang bertujuan untuk mengurai segala residu kimia yang menyebabkan tanah menjadi gembur dan subur.

Pupuk Organik Cair Manutta Gold B bermanfaat untuk memperbaiki struktur tanah yang rusak, menekan pemakaian pupuk kimia sebanyak 50$60 \%$, menambah kuantitas dan kualitas produksi tanaman, melarutkan seluruh residu kimia pupuk anorganik sehingga dapat digunakan secara optimal oleh tanaman, memacu kemampuan adaptasi tanaman terhadap sinar matahari dan lingkungan, membantu kesuburan tanah, yang meliputi kesuburan fisik (menggemburkan tanah), kesuburan kemis (seluruh jenis unsur mikro dan makro lengkap bagi tanaman), dan kesuburan biologis (memperbanyak perkembangan mikroorganisme tanah yang bermanfaat bagi tanaman). Pupuk Organik Cair Manutta Gold dapat digunakan sebagai campuran minum hewan ternak, seperti unggas, sapi, dan lain-lain.

Kandungan unsur hara makro pada Manutta Gold B adalah N 0,18\%; P205 0,05\%; K20 0,48 ppm, sedangkan kadungan unsur hara mikro adalah $\mathrm{C}$ 4,19\% pH 3,82; Fe 0,04\%; Zn 5,3\%; Mn 1,4\%; $\mathrm{B}<0,1 \mathrm{ppm} ; \mathrm{Cu} 2,9$ ppm; $\mathrm{Mo}<0,1$ ppm; $\mathrm{Pb} 0,4$ ppm; $\mathrm{Cd}<0,04$ ppm; Co<0,1ppm; As 0,02 ppm; $\mathrm{Hg}<0,01 \mathrm{ppm}$, serta mikroorganisme positif Bebas dari Mikroba Pathogen (Escherichia coli 0\%, Salmonella sp.).

Fungsi lain dari Manutta Gold B adalah sebagai "pencuci" buah dan sayur. Sebuah iklan di televisi memperkenalkan suatu merk sabun cuci piring yang dapat digunakan dalam mencuci buah dan sayur. Sama halnya dengan fungsi sabun cuci tersebut, yang diklaim dapat membunuh kuman dan membersihkan kandungan berbahaya pada buah dan sayur, fungsi Manutta Gold B juga demikian. Bedanya, Manutta bersifat aman karena terbuat dari bahan organik, serta memiliki kandungan nutrisi yang bermanfaat bagi tanaman, bahkan hewan ternak.

\section{Teknik Penggunaan Manutta}

Cara untuk menghilangkan kandungan kimia berbahaya pada buah dan sayur menggunakan Manutta adalah sebagai berikut:

(1) Siapkan air di dalam wadah, misalnya baskom atau yang lainnya.

(2) Tuang Manutta sesuai kebutuhan (1 takaran tutup botol dapat dicampurkan dengan 25 liter air), ke dalam wadah yang berisi air pada langkah pertama.

(3) Rendam buah atau sayur yang akan diolah/dikonsumsi dalam wadah di langkah kedua. Untuk sayur, jika diperlukan, bisa dipotong-potong terlebih dahulu sebelum diperlukan. Biarkan sekitar 10-15 menit

\section{Teknik Penggunaan FELITA}

Prinsip dasar FELITA adalah wadah berbentuk kotak memanjang ke atas, mempunyai sekat berupa saringan (screen) dan tutup di atasnya, serta dilengkapi dengan keran di bagian dasar wadah. Diameter lubang saringan disarankan tidak terlalu besar agar limbah tidak jatuh melalui celah lubang, dan bercampur dengan produk cair yang dihasilkan. Saat ini banyak dijual bermacam bentuk dan ukuran dari komposter, atau alat pembuat kompos. FELITA hanyalah salah satu 
contoh komposter. Cairan yang dihasilkan dari proses fermentasi tersebut dapat digunakan sebagai pupuk organik dengan mencampurkan dengan air 1:100. ternak. Sisa limbah yang berada di bagian atas screen, dapat dimanfaatkan sebagai kompos dengan mencampurkan tanah, kemudian menimbunnya dengan tanah setinggi 15 $\mathrm{cm}$. Setelah 2-3 minggu kompos siap digunakan.

Pengolahan limbah rumah tangga menggunakan komposter seperti FELITA dan sejenisnya perlu disosialisasikan kepada masyarakat, mengingat penyumbang limbah di Indonesia paling banyak adalah berasal dari rumah tangga. Sosialisasi bisa dilakukan melalui kerja sama dengan perangkat desa agar lebih maksimal dalam mengkoordinir kehadiran peserta.

Melalui sosialisasi, masyarakat dapat memperoleh pengetahuan tentang konsep kerja komposter FELITA. Komposter FELITA dapat dilakukan di dalam rumah atau dapur, dan tidak mengganggu. Prinsip kerja komposter FELITA memungkinkan masyarakat untuk mengolah limbah rumah tangga dengan praktis, mudah, tidak bau, tidak mengundang binatang, tidak kotor, dan aman bagi anak-anak. Dalam melakukan pengolahan, masyarakat tidak diharuskan menggunakan FELITA sebagai komposter. Masyarakat bisa menggunakan atau membuat komposter lain yang memiliki prinsip kerja yang serupa dengan FELITA.

Cara menggunakan FELITA untuk mengolah limbah makanan:

(1) Siapkan FELITA atau wadah lain yang mempunyai prinsip sama dengan FELITA. Pasang screen (saringan) pada FELITA dengan baik, sedemikian hingga ketika limbah dimasukkan ke dalamnya, limbah tidak jatuh ke dasar kotak. Pastikan kran terpasang dengan tepat.

(2) Taburkan aktivator tipis merata pada dasar screen.

(3) Masukkan limbah organik dapur di atas screen, dengan ketinggian maksimal 3-4 cm.

(4) Taburkan aktivator tipis merata.

(5) Tutup kotak FELITA dengan rapat.

(6) Ulangi langkah 2-5 setiap hari, sampai kotak penuh.

(7) Selama minimal dua minggu, limbah makanan akan terfermentasi dan menghasilkan cairan di bagian bawah kotak. Cairan inilah yang digunakan sebagai pupuk cair. Pupuk cair dapat dipindahkan melalui keran ke wadah penyimpanan yang lain.

(8) Ampas limbah yang ada di atas screen dapat digunakan sebagai pupuk kompos, aman dan bernutrisi

\section{Simpulan \\ Simpulan}

Dengan menggunakan bahan limbah pasar menyebabkan harga ransum menjadi lebih murah sebanyak Rp 514/kg dibanding penggunaan dedak padi. Namun demikian penggunaan bahan limbah pasar $(35,7 \%)$ lebih banyak dibandingkan dengan dedak padi $(31,1 \%)$. Selain itu juga terjadi sedikit kenaikan dalam penggunaan bungkil kedele $(0,41 \%)$, akan tetapi terjadi pengurangan dalam penggunaan jagung giling, tepung ikan dan tepung daging. Sedangkan penggunaan bahan-bahan lainnya tidak terjadi perubahan yang cukup nyata.

\section{Saran}

Besar harapan bahan limbah rumah tangga ini tidak mempunyai berbagai kelemahan dalam 
penggunaannya sebagai pakan ternak. Limbah buah dan sayur memang dikenal pada umumnya sangat disukai heawan ternak. Di dalam proses pembuatan bahan-bahan ini telah dilakukan dengan proses ekstraksi yang mampu menghilangkan seluruh racun patogen maupun zat-zat berbahaya lainnya.

Kemungkinannya sangat kecil bahwa bahan limbah rumah tangga ini mengandung berbagai bahan yang bersifat racun atau anti nutrisi yang dapat mengganggu produktivitas ternak.

\section{Daftar Pustaka}

Indriyanti,., Banowati,, \& Margunani. (2015). Pengolahan Limbah Organik Sampah Pasar Menjadi Kompos. ABDIMAS, Vol. 19 No. 1, Juni 2015:43-48.

Kelompok Kerja Teknis BMKG, Kementerian Pertanian, LAPAN, BNPB, dan BPS. (2017). Tren Konsumsi dan Produksi Buah dan Sayur. Buletin Pemantauan Ketahanan Pangan INDONESIA, Vol 8, November 2017.

Khorniawati,Melisa. (2014). Produk Pertanian Organik di Indonesia: Tinjauan Atas Preferensi Konsumen Indonesia Terhadap Produk Pertanian Organik Lokal. Jurnal Studi Manajemen, Volume. 8, No.2 ,Oktober 2014: 171-182.

Loedji, Henri. (2019). 8 Besar Produk Pertanian Indonesia. Dipetik 24 Januari2020, dari PORTONEWS: https://www.portonews.com/2019 /pernik-bisnis/8-besar-produkpertanian-indonesia/.

Pawukir, E. dan Mariyono, J. (2002). Hubungan Antara Penggunaan Pestisida dan Dampak Kesehatan: Studi Kasus di Dataran Tinggi
Sumatera Barat. Manusia dan Lingkungan, Volume. IX,No. 3, November 2002: 126-136. 